\title{
The Semantics of Political
}

\section{Integration: Public Debates}

\section{about the Term 'Expellees' in}

\section{Post-War Western Germany}

\section{R I S ACHUM A N D SAGI SCHAEFER}

In the immediate period following the Second World War the Western occupation zones of Germany received eight million ethnic Germans from Central and Eastern Europe. Initially these newcomers were lumped in Western German discourse under the term 'refugees'. Yet, within less than a decade, the term 'expellees' emerged as a more popular denotation. Scholarship has offered two explanations for this semantic change, emphasising the political influence of both the Allies and the 'expellee' leadership. This article presents a complementary reason for this discursive shift. We argue that 'expellees' marked the symbolic weight that the ethnic Germans offered as expulsion victims in order to balance out German guilt for Nazi crimes.

Refugees or expellees? The question of how to refer to the eight million ethnic Germans who had lost their homes in Central and Eastern Europe after the end of the Second World War and found refuge in the Western occupation zones of Germany, ${ }^{1}$ which were to become the Federal Republic of Germany (FRG) in I949, preoccupied the Western German public in the immediate post-war period. ${ }^{2}$

Sagi Schaefer, Tel Aviv University, Department of History, Ramat Aviv, Tel Aviv 699780I, Israel; sagisc@post.tau.ac.il. Iris Nachum, The Hebrew University of Jerusalem, Faculty of Humanities, Mt. Scopus, Jerusalem 9I9050I, Israel; iris.nachum@mail.huji.ac.il

We would like to thank José Brunner (Tel Aviv) and Kobi Kabalek (Jerusalem) as well as the three anonymous reviewers for their thoughtful comments on an earlier version of this article. Iris Nachum's research leading to this article has received funding from the European Research Council (ERC) under the European Union's Seventh Framework Programme (FP7/2007-2013)/ERC Grant Agreement Number 340I24: 'JudgingHistories: Experience, Judgement, and Representation of World War II in an Age of Globalization'/Principal Investigator: Dan Diner.

1 In this article, the terms West Germany (the Federal Republic of Germany) and East Germany (the German Democratic Republic) are used in reference to the period of statehood following I949, Western occupation zones of Germany and Soviet occupation zone are employed for the pre-state period of I945-49 and Western Germany and Eastern Germany denominate the time-frame spanning both periods.

2 Matthias Jung, Thomas Niehr and Karin Böke, Ausländer und Migranten im Spiegel der Presse: Ein diskurshistorisches Wörterbuch zur Einwanderung seit 1945 (Wiesbaden: Westdeutscher Verlag, 200o), 27.

Contemporary European History, 27, I (2018), pp. 42-58. (C) Cambridge University Press 2017. This is an Open Access article, distributed under the terms of the Creative Commons Attribution licence

(http://creativecommons.org/licenses/by/4.0/), which permits unrestricted re-use, distribution, and reproduction in any medium, provided the original work is properly cited. 
Refugees (Flüchtlinge) and expellees (Vertriebene) were the key concepts, among many others, used, and reflected on, in public forums and in the media. ${ }^{3}$ This article highlights the significance of the public debates about these two collective terms. In the months and years following the war, Germans from the East were generically referred to as 'refugees', but the term 'expellees' gradually gained prominence and became more common, most noticeably with the I953 Federal Expellee Law, which regulated the social and legal status of this population. ${ }^{4}$ In this article we add a new perspective on the reasons for this semantic change. We argue that West Germans agreed to integrate these newcomers and endorse, or at least tolerate, their political demands and terminology, because they benefited from the unique symbolic weight that the ethnic Germans offered as expulsion victims.

The research literature provides two complementary reasons for the shift in terminology to the label 'expellees': first, the US military government ordered the German authorities in its zone of occupation to refer to the uprooted Germans from Central and Eastern Europe by this name $;^{5}$ secondly, the ethnic Germans in question identified themselves as victims of expulsion and lobbied effectively to be recognised as such by the local Western German population. ${ }^{6}$ This discursive change is all the more evident when compared to parallel processes in Eastern Germany. Already in the late summer of 1945 the Soviets imposed on the local administrations in their zone

3 In this article, we refer to this population most often as 'Germans from the East', but also as 'expellees'. Unless stated differently, these terms refer to this population in its entirety and we do not suggest anything implicitly by interchanging them throughout the text. Other terms were in use in post-war West Germany to refer to the Germans from the East, for instance 'evacuees' (Evakuierte) or 'deportees' (Ausgewiesene), but they were less popular and more importantly, less indicative for our analysis here. For this reason, they will not be dealt with in this article.

${ }^{4}$ On the Federal Expellee Law, see Stefan Wolff, The German Question since 1919: An Analysis with Key Documents (Westport: Praeger, 2003), esp. 75-7.

5 Mathias Beer, 'Flüchtlinge - Ausgewiesene - Neubürger - Heimatvertriebene: Flüchtlingspolitik und Flüchtlingsintegration in Deutschland nach I945, begriffsgeschichtlich betrachtet', in idem, Martin Kintzinger and Marita Krauss, eds., Migration und Integration: Aufnahme und Eingliederung im historischen Wandel (Stuttgart: Franz Steiner Verlag, I997), I45-67; Peter Paul Nahm, 'Der Wille zur Eingliederung und seine Förderung', in Eugen Lemberg and Friedrich Edding, eds., Die Vertriebenen in Westdeutschland: Ihre Eingliederung und ihr Einfluss auf Gesellschaft, Wirtschaft, Politik und Geistesleben, vol. I (Kiel: Verlag Ferdinand Hirt, I959), I45 (fn. I).

${ }^{6}$ Michael Schwartz, Vertriebene und 'Umsiedlerpolitik': Integrationskonflikte in den deutschen NachkriegsGesellschaften und die Assimilationsstrategien in der SBZ/DDR 1945 bis 1961 (Munich: R. Oldenbourg Verlag, 2004), 3; Philipp Ther, Deutsche und polnische Vertriebene: Gesellschaft und Vertriebenenpolitik in der SBZ/DDR und in Polen 1945-1956 (Göttingen: Vandenhoeck und Ruprecht Verlag, I998), 95; Karin Böke, 'Flüchtlinge und Vertriebene zwischen dem Recht auf die alte Heimat und der Eingliederung in die neue Heimat: Leitvokabeln der Flüchtlingspolitik', in idem, Frank Liedtke and Martin Wengeler, Politische Leitvokabeln in der Adenauer-Ära (Berlin: Walter de Gruyter, I996), I6I; Martin Wengeler, 'Multikulturelle Gesellschaft oder Ausländer raus? Der sprachliche Umgang mit der Einwanderung seit I945', in idem and Georg Stötzel, Kontroverse Begriffe: Geschichte des öffentlichen Sprachgebrauchs in der Bundesrepublik Deutschland (Berlin: Walter de Gruyter, 1995), 715. On the political activities of the expellee organisations in West Germany, see Samuel Salzborn, Grenzenlose Heimat: Geschichte, Gegenwart und Zukunft der Vertriebenenverbände (Berlin: Elefanten Press, 200o); Pertti Ahonen, 'The German Expellee Organizations: Unity, Division, and Function', in Manuel Borutta and Jan C. Jansen, eds., Vertriebene and Pieds-Noirs in Postwar Germany and France: Comparative Perspectives (Houndmills: Palgrave Macmillan, 20I6), II5-32. 
of occupation the use of the term resettlers (Umsiedler) to denote the four million uprooted ethnic Germans who now resided in this territory. The Soviets considered Umsiedler an accurate translation of the Russian word for resettlers (peresselenjetz) and thereby signalled that the post-war removal of the ethnic German minorities from Central and Eastern Europe was throughout in line with established Soviet policy of population displacement and resettlement. ${ }^{7}$

In the following pages we focus on post-war Western Germany, where, in absolute numbers, not only most of the ethnic Germans from the East sought refuge, but also where, compared to Eastern Germany, public discourse about the expellees could unfold more freely. We suggest that beyond the well-discussed causes in historiography, the semantic turn from 'refugees' to 'expellees' was also a consequence of a Western German social-political process in which, as Robert Moeller has shown, Germans who had fled or been expelled from Central and Eastern Europe became 'the most important representatives of German victimhood' ${ }^{8}$ The pressing need of many West Germans in the immediate post-war years to take on the role of victims as a counterbalance to German guilt and responsibility for major crimes committed during the Nazi era and the prominent participation of the expellee organisations in the construction of this powerful victim narrative, have been the subject of several publications. ${ }^{9}$ Nevertheless, in the historiography on German victimhood, the rhetorical function of the term expellees has so far found little attention. ${ }^{10}$ As Pertti Ahonen recently stated: 'the terminology used in public discussions of the German expellees and their expulsions was one key factor that has often been overlooked. The word "expellee" (Vertriebene) was crucial in itself."11 By placing the term Vertriebene at the centre of our analysis, Moeller's and others' findings on the significance of victimhood for the Western German public are further substantiated.

In the first part of the article, we deal with the two reasons which are given in the research literature for the semantic transcoding from 'refugees' to 'expellees' in post-war Western Germany. In the second part of the article, we pursue two aims: first, we analyse how the renaming of the Germans from the East found expression in the Western German press in the period following the war up until the enactment

7 Michael Schwartz, "Vom Umsiedler zum Staatsbürger”: Totalitäres und Subversives in der Sprachpolitik der SBZ/DDR', in idem, Dierk Hoffmann and Marita Krauss, eds., Vertriebene in Deutschland: Interdisziplinäre Ergebnisse und Forschungsperspektiven (Munich: R. Oldenbourg Verlag, 2000), I35-7.

${ }^{8}$ Robert G. Moeller, War Stories: The Search for a Usable Past in the Federal Republic of Germany (Berkeley: University of California Press, 200I), 3.

9 See, for instance, Gilad Margalit, Guilt, Suffering, and Memory: Germany Remembers Its Dead of World War II (Bloomington: Indiana University Press, 20Io); Eva Hahn and Hans Henning Hahn, Die Vertreibung im deutschen Erinnern: Legenden, Mythos, Geschichte (Paderborn: Ferdinand Schöningh, 20Io) and, most notably, Moeller, War Stories.

10 Among the few exceptions, Salzborn, Grenzenlose Heimat, 40-I.

11 Pertti Ahonen, 'On Forced Migrations: Transnational Realities and National Narratives in Post-I945 (West) Germany’, German History, 32, 4 (20I4), 602. 
of the Federal Expellee Law in I953. ${ }^{12}$ The use of news coverage is instructive insofar as the media highly influenced the Western German public's perception of non-local Germans. ${ }^{13}$ Second, by referring to specific newspaper reports and articles, we show how the shift to the nomenclature 'expellees' entailed an added value to the German self-representation as victims of the Second World War.

\section{The Nomenclature of the US Military Government}

The post-war removal of the German minorities from Central and Eastern Europe was connected, among other things, to the immense popularity Nazism had enjoyed among these populations before and during the Second World War. ${ }^{14}$ Plans for a future resettlement of ethnic Germans from their homeland in the East were debated as early as May I940 by scientific advisors to the British Foreign Office and prominently advanced by the exiled Czechoslovak government in London. ${ }^{15}$ Towards the end of the war, the die was cast. According to Matthew Frank, 'there was ... a broad consensus within the United Nations that population transfer would have to play some role in the post-war settlement in Central and Eastern Europe, if only to help create viable and stable nation-states as a barrier against a revival of German militarism and expansionism'. ${ }^{16}$ In a speech delivered in the House of Commons on Is December I944, the British prime minister, Winston Churchill, declared accordingly that he supported 'the total expulsion of Germans from the areas to be acquired by Poland in the west and north, for expulsion is the method which, so far as we have been able to see, will be most satisfactory and lasting'. ${ }^{17}$ Following Germany's unconditional surrender on 8-9 May I945, the Allies finally

12 This section of the article is partly based on research results presented in Sagi Schaefer (Hanani), "'Guilty" and "Less Guilty", "Germans" and "Less Germans": The Integration of the Germans from the East in the West German Discussion and their Impact on it', M.A. thesis, Tel Aviv University, 2003. In Hebrew.

13 Gerald Neumann, Die Medien und die Flüchtlingsfrage in Bayern von 1945 bis 1953 (Munich: iudicium, I994), I4.

14 E. Hahn and H.H. Hahn, Vertreibung im deutschen Erinnern, IO2, I22-3. On the post-war removal of the German minorities from territories in Central and Eastern Europe as part of a larger Soviet and British project of creating ethnically homogeneous nation-states in this area, see Matthew Frank, Expelling the Germans: British Opinion and Post-1945 Population Transfer in Context (Oxford: Oxford University Press, 2008), 44-5.

15 Ibid., 47-52; Detlef Brandes, Der Weg zur Vertreibung 1938-1945. Pläne und Entscheidungen zum 'Transfer' der Deutschen aus der Tschechoslowakei und aus Polen (Munich: R. Oldenbourg Verlag, 2005 [200I]), esp. 28-30; Martin David Brown, Dealing with Democrats: The British Foreign Office and the Czechoslovak Émigrés in Great Britain, 1939 to 1945 (Frankfurt am Main: Peter Lang Verlag, 2006), 256-7, 278-8I.

16 Matthew Frank, 'Reconstructing the Nation-State: Population Transfer in Central and Eastern Europe, I944-8', in Jessica Reinisch and Elizabeth White, eds., The Disentanglement of Populations: Migration, Expulsion and Displacement in Postwar Europe, 1944-9 (Houndmills: Palgrave Macmillan, 20II), 34.

17 Winston Churchill, 'Soviet-Polish Frontier. A Working Agreement Necessary', Vital Speeches of the Day, II, 6 (I945), I65. On the Allies' agreement during and after the war regarding the need to remove the German population from Central and Eastern Europe, see Norman M. Naimark, Fires of Hatred: Ethnic Cleansing in Twentieth-Century Europe (Cambridge: Harvard University Press, 2002), IO8-II. 
approved at the Potsdam conference (I7 July-2 August I945) 'the transfer to Germany of German populations, or elements thereof, remaining in Poland, Czechoslovakia and Hungary' and agreed 'that any transfers that take place should be effected in an orderly and humane manner'. ${ }^{18}$

In the months following the war, the US authorities referred to the German population arriving from Central and Eastern Europe in their zone of occupation in Germany as 'refugees'. It is noteworthy that not only were those Germans who were affected by the Potsdam agreement subsumed by the Americans under this term, but so were virtually all Germans who had abandoned their domicile during and after the war. That diverse group included civilians who had lost their places of residence on German territory as a result of the Allied air raids in the years I943 and I944 as well as ethnic Germans who had been forcibly driven out from a number of Central and Eastern European states by the local populations in the course of the so-called 'wild expulsions' that took place in the months and weeks before the signing of the Potsdam agreement. ${ }^{19}$ It was not until the end of 1945 that the US occupation authorities realised the need to address the immense refugee problem in their occupation zone, and subsequently went on to distinguish between 'refugees' and 'expellees'. Thus, at the instigation of the Americans, the term expellees was employed in a plan adopted on 20 November 1945 by the Allied Control Council, which acted as the governing body for occupied Germany, regarding arrival quotas for displaced Germans originating from Poland, Czechoslovakia and Hungary: ${ }^{20}$

An expellee is considered to be a member of a German minority whose normal place of residence is in a country outside Germany or in that portion of Germany east of the Oder and Neisse Rivers now under Polish administration, and who is to be expelled therefrom and resettled within occupied Germany. On the other hand, a refugee is considered to be a German civilian whose normal place of residence is in occupied Germany and who is homeless or at some distance from his home because of the war. ${ }^{21}$

Not only did the US nomenclature confirm the 'orderly and humane transfer' of the German population from the East, it also legitimised in retrospect the wild expulsions of Germans in the pre-Potsdam period. And more than that - the US definition of the term expellees expressed both the intention of the US government of permanently settling the uprooted ethnic Germans within occupied Germany as well the expectation that they would assimilate into German society. ${ }^{22}$

Consequently, the Americans spoke of the expellees as 'non-repatriable Germans' and expected the German administrations in the US occupation zone to adopt this language regulation. Yet, the German authorities followed the request only hesitantly and clung to the term refugees. Besides widespread rejection of the newcomers by the local German population - a point that will be discussed below - the public in the

\footnotetext{
18 'Potsdam Declaration. Text of Big Three Communiqué', Vital Speeches of the Day, II, 2I (I945), 672.

19 Beer, 'Flüchtlinge - Ausgewiesene', I52-3.

20 Ibid., I56.

21 Military Government of Germany, Displaced Persons, Stateless Persons and Refugees. Monthly Report of Military Governor, no. 6 (US zone, 20 Jan. I946), 3.

22 Beer, 'Flüchtlinge - Ausgewiesene', i56-7.
} 
Western zones of occupation was reluctant to accept the idea that they were indeed to be seen as permanent additions to German society. ${ }^{23}$ Finally, in September I946, Vertriebene was introduced into German officialese as a translation for the English term expellees chosen and promoted by the American occupiers. ${ }^{24}$ And, from I949, West German officials began using the term refugees (Flüchtlinge) exclusively for those Germans who migrated from East Germany to the West. ${ }^{25}$

Acting as a veritable mirror image of the Western zones, the Soviet zone of occupation, which came to be known as the German Democratic Republic (GDR) in I949, experienced a semantic transcoding in roughly the same time. In February 1947 the administrators there were instructed to use the term new citizens (Neubürger) for all those ethnic German 'resettlers' (the so-called Umsiedler) who had left the quarantine camps and taken up residence in a municipality. In this way, representatives of both the Soviet Military Administration in Germany and of the Socialist Unity Party of Germany (Sozialistische Einheitspartei Deutschlands; SED), the dominant political party in Eastern Germany from I946 on, made clear that they considered the expulsion issue as resolved, that they expected the newcomers from Central and Eastern Europe to rapidly meld with the local population and that they did not intend to give them special treatment. In the early I950s the entire expulsion topic became taboo in the GDR and, consequently, the term Neubürger disappeared from public discourse. ${ }^{26}$ As will be shown in the following pages, the public discussion about the expellees took a different course in Western Germany.

\section{The Nomenclature of the Expellee Organisations}

In the immediate post-war months, the Germans from the East who settled in the Western occupation zones of Germany commonly referred to themselves as refugees, yet, within a short time, they began to call themselves expellees, or more specifically and meaningfully, 'expellees from the homeland' (Heimatvertriebene). Thus, for instance, from I 946 on, they founded several self-help voluntary associations, in whose names the word 'expellees' explicitly appeared. ${ }^{27}$ As the umbrella noun 'refugees' had acquired negative connotations among the local public and a distinct air of foreignness, it had become a less attractive self-description by that time. ${ }^{28}$ More

23 Ibid. I57-6I. On the conflicts between the local German population and the refugees, see Daniel Levy, 'Integrating Ethnic Germans in West Germany: The Early Postwar Period', in David Rock and Stefan Wolff, eds., Coming Home to Germany? The Integration of Ethnic Germans from Central and Eastern Europe in the Federal Republic (New York: Berghan Books, 2002), I9-37.

24 Beer, 'Flüchtlinge - Ausgewiesene', I6r.

25 Ibid., I66.

26 Schwartz, "Vom Umsiedler zum Staatsbürger"”, I35-6, I49-62.

27 Böke, 'Flüchtlinge und Vertriebene', I53-5.

28 Ibid., I59-6I. Because all non-locals were called Flüchtlinge, the term gradually came to reflect all the feelings of foreignness, menace, hostility and blame for the economic hardship that the local residents felt toward the newcomers, and therefore was often used in a derogatory sense. On the pejorative depiction of the 'refugees' in contemporary literature, see, for instance, Horst Mönnich, Das Land ohne Träume. Reise durch die deutsche Wirklichkeit (Braunschweig: Georg Westermann Verlag, I954), 57-65. 
importantly, by means of adopting an exclusive nomenclature, the 'expellees' tried both to claim a special status in German society as well as to distinguish themselves from other non-local groups. ${ }^{29}$ Most notably, they wished to avoid being lumped in with the constant stream of migrants from the Soviet occupation zone - despite the fact that a considerable portion of these persons were expellees themselves, that is, ethnic Germans from the East who initially found refuge in the Soviet zone and subsequently migrated westwards. ${ }^{30}$ Many residents of this zone decided to cross the border westward due to a sense of danger and lack of political freedom under the Soviet regime, but the more common cause was their wish to improve their prospects of earning a living. Upon arrival in the West, their social needs and hardships closely resembled those of the early waves of expellees; they too had arrived almost destitute and were housed in camps. ${ }^{31}$

The leaders of the expellee associations feared, not without good reason, that if the local Germans were to speak of the German people from the East and of the German population from the Soviet zone equally as refugees, it might reinforce the widespread notion in Western Germany that the ethnic Germans had left Central and Eastern Europe voluntarily. In a similar vein, it might cast serious doubt on the reliability of the expellees' narrative of having been brutally forced out from their homeland against their will because of their German identity. ${ }^{32}$ For this reason, the linguist Lutz Mackensen, who had participated in the Germanisation of the Wartheland (the former Greater Poland) during the Third Reich, found fault with calling the Germans from the East refugees and not expellees. In I959 he emphasised that, contrary to the expellees, the refugees' 'farewell from the old homeland is indeed carried out reluctantly and under external pressure, but by one's own decision'. ${ }^{3}$ While 'refugees' conveyed in this sense the idea of a conscious decision to flee from danger, 'expellees' implied a passive suffering of an injustice, resonated a salient atmosphere of violence and stressed the victim status of the persons concerned. In addition, unlike 'refugees', the term expellees did not merely describe a present static situation; rather it suggested that the situation had been caused by the action of an outside agent: if there are expellees, then there must also be someone who expelled them and who bears responsibility for their situation. Against this backdrop Vertriebene developed into a strong anti-communist, 'Cold War construct. . . It highlighted the violent arbitrariness of the expulsions and pointed the finger at the USSR and its

29 Böke, 'Flüchtlinge und Vertriebene', I56, I6I.

30 Between I949 and I96I a third of the migrants from East Germany were expellees. Helge Heidemeyer, 'Vertriebene als Sowjetflüchtlinge', in Hoffmann, Krauss and Schwartz, eds., Vertriebene in Deutschland, 239.

31 On the integration in Western Germany of the new arrivals from the Soviet occupation zone, and subsequently from the GDR, see the excellent analysis in Volker Ackermann, Der 'echte' Flüchtling: Deutsche Vertriebene und Flüchtlinge aus der DDR 1945-1961 (Osnabrück: Universitätsverlag Rasch, I995), esp. 96-III.

32 Ibid., 70-I.

33 Lutz Mackensen, 'Die deutsche Sprache in und nach der Vertreibung', in Lemberg and Edding, eds., Vertriebenen in Westdeutschland, 264. 
East European allies as the primary culprits behind them'. ${ }^{34}$ The German philosopher Hermann Lübbe underlined this specifically political meaning of the term expellees: 'this word has unmistakably a precise political sense. It combines the memory of the homeland with the emphasis on the illegitimate violence of the exodus, and it conserves in this way in conjunction with the political neologism "right to the homeland" the entitlement to return to the mentioned areas'. ${ }^{35}$ In addition, the term Vertriebene also implied a tough anti-Potsdam stance and included the demand to revise of the Oder-Neisse line, that is the post-war German-Polish border that was drawn in the framework of the Potsdam agreement transferring a large part of Germany's territory to Poland. ${ }^{36}$

To be sure, this politicisation of semantics was not completely at odds with the Western Allies' geopolitical interests. In the context of increasing tension between the Anglo-Americans and the Soviet Union over Germany, the United States itself tactically placed the volatile Oder-Neisse topic in the international spotlight. This was most evident in Secretary of State James F. Byrnes' Stuttgart speech of 6 September 1946, in which he hinted at the provisional character of the GermanPolish frontier. For one thing he declared that the 'United States will support revision of these frontiers in Poland's favor', yet, in line with the Potsdam agreement, he also emphasised that the 'extent of the area to be ceded to Poland' will only be decided in a final peace settlement. ${ }^{37}$ But still, although the Anglo-Americans clearly regretted the territorial compromise with Stalin at Potsdam, by the early I950s they were equally determined to preserve the Cold War status quo. Consequently, the stubborn revisionist claims of the expellees to the 'right to the homeland' hardly found a sympathetic ear in Washington or London. ${ }^{38}$

Indeed, throughout the entire post-war period, the expellee spokespersons repeatedly declared that all expellees should march together in their fight for the 'right to the homeland' (Recht auf die Heimat), which could only be fulfilled through the collective return of millions of displaced ethnic Germans to their lost homes behind the Iron Curtain. ${ }^{39}$ Here, as in other circumstances, the term expellees created 'an impression of seeming national homogeneity'. ${ }^{40}$ Despite their political diversity, it echoed not only a supposed anti-communist unity among the Germans from the

34 Ahonen, 'German Expellee Organizations', I23.

35 Hermann Lübbe, 'Der Streit um Worte. Sprache und Politik', in Hans-Georg Gadamer, ed., Das Problem der Sprache (Munich: Wilhelm Fink Verlag, I967), 360.

36 Pertti Ahonen, After the Expulsion: West Germany and Eastern Europe 1945-1990 (Oxford: Oxford University Press, 2003), 40.

37 James F. Byrnes, 'A Self-Governing Germany', Vital Speeches of the Day, I2, 23 (I946), 709. On Byrnes' Stuttgart speech, see Ahonen, After the Expulsion, 26-7.

38 Moeller, War Stories, 35-6.

39 Andrew Demshuk, "What was the "Right to the Heimat"? West German Expellees and the Many Meanings of Heimkehr', Central European History, 45, 3, (2012), 523. For examples of how the West German press mentioned the 'right to the Heimat' in reports about or quotes from the expellee organisations, see Marion Gräfin Dönhoff, 'Heimat im Osten', Die Zeit, I8 May I950, I; 'Heimat zwischen Haff und Meer', Frankfurter Allgemeine Zeitung, 28 Feb. I95I, 5.

40 Ahonen, 'German Expellee Organizations', I23. 
East, but also obscured, for instance, the fact that they had encountered very different experiences of more or less forced migration in the mid-I94Os - experiences that ranged from fleeing before the Red Army to brutal deportations. ${ }^{41}$

Due to the expellee lobbies' strong foothold in the West German party system, Vertriebene and Heimatvertriebene (the revisionist and not the US meaning associated with these terms) soon developed into key concepts in West German political discourse. ${ }^{42}$ Thus, for instance, in 1949 both the liberal-conservative Christian Democratic Union (Christlich Demokratische Union; CDU) as well the Social Democratic Party of Germany (Sozialdemokratische Partei Deutschlands; SPD) anchored these terms in their respective party programmes. ${ }^{43}$ And with time the West German public came to consider the so-called 'refugees from the Soviet zone' (Sowjetzonenflüchtlinge) a different category than the expellees. In this vein, the I953 Federal Expellee Law differentiated between three groups of German newcomers: (a) expellees (Vertriebene): legally defined as 'German citizens or ethnic Germans who had lost their homes as a consequence of flight or expulsion'; ${ }^{44}$ (b) expellees from the homeland (Heimatvertriebene): those expellees whose prewar places of residence were on the territory of the state which they had subsequently to leave; (c) refugees from the Soviet zone (Sowjetzonenflüchtlinge): 'German citizens or ethnic Germans who had had to flee the Soviet zone of occupation because of threats to their lives or freedom'. ${ }^{45}$

The term 'expellees' as used by the leaders of the Germans from the East and as used by the US military government in Germany thus articulated two different views. Certainly, as we have shown, in the period following the war, both the Americans and the expellees tried by means of introducing this term in the public discourse to distinguish the ethnic German newcomers from other displaced and uprooted groups in the Western zones of occupation. However, while the US version of the term articulated the legitimacy of the forced population transfer of Germans after I945 and - in line with the US melting pot ideal - expressed the vision of their permanent

41 Ibid., I23-5.

42 Christian Lotz, Die Deutung des Verlusts: Erinnerungspolitische Kontroversen im geteilten Deutschland um Flucht, Vertreibung und die Ostgebiete (1948-1972) (Köln: Böhlau Verlag, 2007), 2; Böke, 'Flüchtlinge und Vertriebene', I6I.

43 Ibid., I55.

44 'Gesetz über die Angelegenheiten der Vertriebenen und Flüchtlinge (Bundesvertriebenengesetz, BVFG)', Bundesgesetzblatt, I, 22 (22 May I953), 203 (Begriffbestimmungen); Wolff, German Question, 76. More than the term Vertriebener, the term Heimatvertriebener stressed the loss of the homeland 'in the East' and thus pointed to the victim status of the expellees. The legal differentiation between those terms was of practical relevance within the frame of the I953 West German Equalization of Burdens Law (Lastenausgleichsgesetz), that regulated, among others, the compensation of material damages inflicted upon ethnic Germans in the course of the expulsion. Because of their traumatic uprooting from the homeland, Heimatvertriebene were eligible to a ten percent premium (the so-called Entwurzelungszuschlag). See Wolfgang Rüfner, 'Probleme des Lastenausgleichs aus juristischer Sicht', in Paul Erker, ed., Rechnung für Hitlers Krieg. Aspekte und Probleme des Lastenausgleichs (Heidelberg: Verlag Regionalkultur, 2004), 25.

45 'BVFG', Bundesgesetzblatt, I, 22 (22 May I953), 203 (Begriffbestimmungen); Wolff, German Question, 76. 
assimilation into German society, ${ }^{46}$ the expellees associated with it the illegitimacy of the expulsion and the hope of return to their old homeland, even though, at the same time, they demanded equality with the local German population and pressed for financial assistance for integration into the host society. ${ }^{47}$ As it turned out, the young Federal Republic of Germany responded to their demands by pushing ahead with a 'policy of incorporation' that aimed at fostering the expellees' economic integration, while at the same time, and in diametrical opposition to the policy in East Germany, promoting the public expression of their lasting attachment to their areas of origin. ${ }^{48}$

\section{The Nomenclature in the Western German Press}

In this section we follow the changing balance struck by different newspapers and their editors, showing how they depicted the Germans from the East, and topics related to them, and how they used the words Flüchtlinge and, increasingly, Vertriebene in the press coverage during the first eight post-war years. Based on an empirical study of more than a thousand newspaper items, ${ }^{49}$ we then present a third interpretation for the change in terminology from Flüchtlinge to Vertriebene. We argue that this semantic shift reflected the growing public awareness of the unique symbolic political value that the acceptance of the expellees' narrative and nomenclature could add to the Western German self-identification as war victims.

Until the self-dissolution of the military governments in the Western occupation zones on 2I September 1949, the local media remained under the de facto control of the Western occupying powers (de jure, this control ended only on 5 May I955 with the official termination of the occupation). ${ }^{50}$ Consequently, the local newspapers had to align themselves with the guiding principles of the Western Allies: expellee assimilation to the German host society - yes; return to their old homeland - no. In addition to the Allied supervision of the press, the German newspaper publishers faced an acute paper shortage, which made it difficult to expand their readership and gave the occupation forces an additional instrument of control via paper rations. ${ }^{51}$

In practice Allied press control meant that any item that could be seen as an affront to the occupation authorities or as a criticism of the policies of the victorious powers of the Second World War, such as the Potsdam decisions, could not be

46 Ackermann, 'Echte' Flüchtling, 40.

47 Böke, 'Flüchtlinge und Vertriebene', I57.

48 Michael Schwartz, 'Assimilation versus Incorporation: Expellee Integration Policies in East and West Germany after I945', in Borutta and Jansen, eds., Vertriebene and Pieds-Noirs, esp. 77.

49 Schaefer (Hanani), "Guilty" and "Less Guilty",.

50 Neumann, Medien und die Flüchtlingsfrage, 4I. On the Allied press control in Germany, see Harold Hurwitz, 'Die Pressepolitik der Alliierten', in Harry Pross, ed., Deutsche Presse seit 1945 (Bern: Scherz Verlag, I965), 27-55.

51 The Süddeutsche Zeitung, for instance, which began in the immediate post-war period as a Bavarian local newspaper with an impressive circulation of 400,000 copies, had its numbers down to 250,000 copies in I949, (although by then it appeared no longer two or three times per week, but had become a daily). Neumann, Medien und die Flüchtlingsfrage, 247. 
published. ${ }^{52}$ While articles that spoke in favour of the 'right to the homeland' were hence banned from print, the occupying powers encouraged the dissemination of items that showed the urgent need of accepting the expellees as an integral part of German society. In this regard, the Allied Control Council mandated that the refugee and expellee question should not be presented as a political but as a social issue. ${ }^{53}$ Failure to follow these rules resulted in reprimands and sanctions for the German newspaper publishers. ${ }^{54}$ Therefore, when Werner Friedmann, the chief editor of the Süddeutsche Zeitung, published an article on 4 June I946 entitled 'They Harvested Hatred', in which he denounced the harsh expulsion methods directed against the German population in Czechoslovakia, the newspaper was severely rebuked by the US occupation authorities. ${ }^{55}$ In the following month, its paper supply was cut and it was allowed to print only four pages per issue. ${ }^{56}$ Yet in general, the press complied with the regulation of the Allied Control Council. It reported rather critically on the strong reservations of the local German population towards the Germans from the East, attempted to foster understanding for them and repeatedly called for their integration into German society. ${ }^{57}$

Indeed, initially, many West Germans had difficulties accepting the newcomers as full members of Western German society. They were up to their necks in their own problems and were not eager to take in millions of additional people. The little they still had after the war was a lot compared to what the Germans from the East had brought with them, and now they were being required to share even this little bit. ${ }^{58}$ Moreover, in their eyes, the expellees were not 'real Germans'. ${ }^{9}$ Some of the ethnic Germans from Central and Eastern Europe (as well as some of the locals) were not fluent in standard German (Hochdeutsch) and spoke dialects that were sometimes incomprehensible to the locals (who many times themselves spoke in dialect that the newcomers could not follow). Furthermore, the expellees brought with them customs and traditions that differed from those of the areas in Germany in which they were settling. ${ }^{60}$ All these factors made the host society reluctant to welcome them, as shown by a US opinion poll conducted among locals of Baden-Württemberg in November 1946, in which only half of the respondents

52 Ibid., 35,38 .

53 Ibid., 249.

54 Ibid., 38.

55 Werner Friedmann, 'Sie ernteten den Haß', Süddeutsche Zeitung, 4 June I946, 3.

56 Neumann, Medien und die Flüchtlingsfrage, 38, 247, 250.

57 Ibid. 56, 58-6I.

58 For a good example of the resistance that the requirement to absorb the German newcomers from the East evoked, for instance, in a rural district of Bavaria, see Barbara Sallinger, Die Integration der Heimatvertriebenen im Landkreis Günzburg nach 1945 (Munich: Verlag Ernst Vögel, I992), 98-Io8.

59 Neumann, Medien und die Flüchtlingsfrage, 45-7.

${ }^{60}$ On the social and psychological obstacles faced by the expellees (and refugees) in West Germany, see Rainer Schulze, 'Growing Discontent: Relations between Native and Refugee Populations in a Rural District in Western Germany after the Second World War', in Robert G. Moeller, ed., West Germany under Construction: Politics, Society, and Culture in the Adenauer Era (Ann Arbor: University of Michigan Press, I997), 53-72. 
considered the newcomers as fellow citizens. ${ }^{61}$ The ethnic Germans were pushed out from Central and Eastern Europe because they perceived themselves or were perceived by others to be Germans. But ironically, upon reaching Western Germany they discovered that their being German was questioned by the local population. Hence, the extent of their 'Germanness' was central not only to the decision to expel them but also to the question of their integration and absorption in Western Germany.

The perceived foreignness made it easier for the local residents to object to the task assigned to them. If the newcomers were not Germans, or if they could be viewed as 'less German', then one had no obligation to share with them the little that one still had. This common attitude was displayed in the newspapers' efforts to urge the local population to help the expellees because these were German co-nationals in need. ${ }^{62}$ In an editorial dated 5 September I946, the conservative co-founder of the Hamburg-based newspaper Die Zeit, Richard Tüngel, appealed to the 'obligation' of the local Germans 'to assist our German brethren in their distress in every possible way'. ${ }^{63}$ But this call to solidarity was not consistently reflected in the early post-war years even in Tüngel's newspaper. Very often, news reports and articles depicted these people as having not only a different fate but also different traits than the 'real' Germans. ${ }^{64}$ For example, the weekly news magazine Der Spiegel, founded in I947, described a dispute between residents of Lübeck in the British zone of occupation over a plan to rebuild the city. When the architect in charge - a German from the East - proposed changes in the old city, a group of long-time residents issued a manifesto stating: 'the looming danger, that our old Hansa city loses its . . . unique character under the daily growing influence of foreign forces with no indigenous roots, can only be averted if a unanimous resistance puts a halt to this danger' ${ }^{65}$

Against this background, newspapers served as a central arena in which the question of the right collective term for the Germans from the East was debated

61 R.M. Douglas, Orderly and Humane: The Expulsion of the Germans after the Second World War (New Haven: Yale University Press, 20I2), 3I4. For detailed description and analysis of the unwelcoming attitude of the local Germans to the expellees, see ibid., 30I-25; Mathias Beer, Flucht und Vertreibung der Deutschen: Voraussetzungen, Verlauf, Folgen (Munich: Verlag C.H.Beck, 20II), 94-I20; Andreas Kossert, Kalte Heimat: Die Geschichte der deutschen Vertriebenen nach 1945 (Munich: Siedler Verlag, 2008).

62 Neumann, Medien und die Flüchtlingsfrage, 56-61, 64-8. The Süddeutsche Zeitung reported, for instance, that local women who refused to house refugees in their homes were sentenced to living in a refugee camp for a month. 'Zu Flüchtlingslager verurteilt', Süddeutsche Zeitung, 25 Feb. I947, 2.

63 'Haben wir die Pflicht, unseren deutschen Brüdern in ihrem Unglück in jeder Weise zu helfen'. Richard Tüngel, 'Ohne Heimat', Die Zeit, 5 Sep. I946, I.

64 The sense of foreignness is evident between the lines in many articles. See, for example, Jan Molitor (= Josef Müller-Marein), 'Die Not der Menschen ohne Heim und Heimat', Die Zeit, 2 Jan. I947, 9.

65 Der Spiegel, I3 Oct. I949, 8. When a school principal in a village in Lower Saxony - a German from the East whose Polish-sounding name the locals had difficulty pronouncing - adopted 'defeatist' stances vis-à-vis the occupying powers and fired a teacher who expressed nationalist views in class, the parents wrote to the mayor that they demand 'only German teachers' who act 'in a German spirit' (im deutschen Sinne). 'Im deutschen Sinne', Der Spiegel, 4 Aug. I949, Io. In another article that year, Der Spiegel mentioned an objection by local residents to the participation of Germans from the East in the upcoming vote on a constitution for the Federal Republic of Germany. 'Geistlicher Rat teuer', Der Spiegel, I2 Mar. I949, IO. 
and negotiated. When they were mentioned in the press in the immediate post-war months, it was usually as one more group of displaced and uprooted persons on German territory, alongside prisoners of war, evacuees from the bombings, released inmates of National Socialist concentration camps or former forced labourers. The absence of any distinction between the expellees and other groups of nonlocals was, for instance, salient in the few thin issues of the Süddeutsche Zeitung from I945. Terms like 'people without a homeland' (Heimatlose), 'strangers' (Ortsfremde) and especially refugees (Flüchtlinge) were used in these issues to describe all people living in the Western occupation zones who were not their original inhabitants. ${ }^{66}$ Yet soon the request expressed both by the Western occupation authorities as well as by the expellee representatives to distinguish the expellees from the other groups was echoed in the press. Therefore, in his above-mentioned editorial, Richard Tüngel stated:

They are called 'refugees' in Germany, but this word is wrong. It sounds as though these people voluntarily chose to leave, in order to relieve themselves of some pressure. . . These are not refugees, but expellees. People, whom the war chased away from their homes and who have been forbidden to return to their homeland, as well as others forcibly evicted after the war from regions where their ancestors had been residing for centuries. ${ }^{67}$

Nevertheless, until the end of the I940s, this newspaper, like others, was still using Flüchtlinge to refer to the Germans from the East in article titles, even when the body of the text actually called them expellees. ${ }^{68}$

The growing influx of migration from the Soviet zone and subsequently from the GDR provided support for the semantic distinction between refugees and expellees in the late I94Os, because although many of those newer migrants argued that they had fled persecution, they were almost never expelled by the authorities of Eastern Germany. The fact that the press and the population gradually adopted the terms and narratives preferred by the expellees themselves, shows also, at least to a certain degree, that newspaper editors, reporters, as well as the residents of Western Germany had become better acquainted with expellees and that the expellee organisations were growing in prominence in public discussion. Consequently, towards the end of I949 the press clearly distinguished the expellees from other dislocated groups. In a small article headlined 'An Umbrella Organisation for the Refugees', the Frankfurter Allgemeine Zeitung reported, for example, on the merger of the organisations of the refugees from the Soviet zone and added a line clarifying that this new body had no connection whatsoever with the organisations of the expellees. ${ }^{69}$ Four years later the same newspaper printed an article on a new alliance of migrants from the GDR who were demanding the equalisation of social benefits with those of the expellees,

66 See, for example, 'Die Zone der Heimatlosen', Süddeutsche Zeitung, I9 Oct. I945, 4.

67 Tüngel, 'Ohne Heimat'.

68 Towards the end of the decade, there were many cases of such discrepancies between headlines and articles. See, for example, 'Flüchtlingsproblem hat bedrohliches Stadium erreicht', Süddeutsche Zeitung, II Nov. I948, 2; 'Flüchtlinge fordern Sonderministerium', Süddeutsche Zeitung, I5 Mar. I949, 2; Robert Strobel, 'Flüchtlingsministerium', Die Zeit, I Sept. I949, 2; Ernst Friedlaender, 'Es gibt keine Flucht vor den Flüchtlingen', Die Zeit, 22 Sept. I949, I.

69 'Eine Dachorganization der Flüchtlinge', Frankfurter Allgemeine Zeitung, I7 Nov. I949, 5. 
under the title 'A Coming-Together of All the Refugees'. ${ }^{70}$ Unlike in late I949, this time the editors did not consider any conceptual clarification regarding the collective terms expellees and refugees necessary, which shows the firm naturalisation of the terminology used for these two population groups in the newspapers and in society at large by 1953 .

In addition, in light of the developing Cold War, none of the Western Allies, least of all the US occupation forces, remained as strict in enforcing the above-mentioned press regulations very long. As the Allies eased their supervision on the media, especially after the founding of the Federal Republic of Germany on 23 May I949, and as West German society became more self-confident, West German newspapers tended to break out of these constraints more often. ${ }^{71}$ The post-I949 West German press formed then a public platform in which the boundaries of legitimate discussion topics were constantly negotiated, and often, transgressed. As we will see below, especially when reporting on or discussing issues related to the Germans from the East, newspaper editors and publishers increasingly broached sensitive questions, such as the revision of the Potsdam agreement or Allied war crimes against German civilians, which were out of bounds in most other contexts. And, just as importantly, when publicly discussing such explosive topics, the press helped to spread the expellees' terminology and narrative.

To be sure, even under Allied press control the newspapers had informed on the severe fate of the ethnic Germans during and after the expulsion. Nevertheless, until the beginning of I949, editors had clearly refrained from promoting the idea of the Germans' return to their old homelands or from calling them Heimatvertriebene. This changed, however, when the representatives of the expellees from Czechoslovakia started publicly commemorating the loss of their homeland on 9 October 1949, and when, a year later, other expellee organisations joined the festivities that came to be known as 'Day of the Homeland' (Tag der Heimat). ${ }^{72}$ Judged by the references in the national press, this annual event contributed to the growing popularity in the West German public discourse of the term 'expellees from the homeland' as well as of the expellees' claim to return to their lost homes. ${ }^{73}$

Simultaneously, West German newspapers began to criticise the Allies' post-war policy regarding the German minorities in Central and Eastern Europe in general and demanded the revision of the Potsdam agreement in particular. ${ }^{74}$ The local Passauer Neue Presse, for example, which had a circulation of 103,400 copies at the end of I $948,{ }^{75}$ not only deplored at the beginning of I 949 'the millions of Germans who

70 'Zusammenschluß aller Flüchtlinge', Frankfurter Allgemeine Zeitung, 2 Mar. I953, 3.

71 Neumann, Medien und die Flüchtlingsfrage, 70.

72 Tobias Weger, 'Volkstumskampf' ohne Ende? Sudetendeutsche Organisationen, 1945-1955 (Frankfurt am Main: Peter Lang Verlag, 2008), 473-4.

73 See, for example, 'Tag der Heimat', Süddeutsche Zeitung, 8 Oct. I949, 2; 'Flüchtlinge feiern “Tag der Heimat”, Süddeutsche Zeitung, Io Oct. I949, 4; 'Vertriebene fordern Rückkehr', Frankfurter Allgemeine Zeitung, 22 May I950, 3; 'Eines Tages wieder deutsch', Frankfurter Allgemeine Zeitung, I6 Oct. I950, 3; 'Menschenrecht auf die Heimat', Frankfurter Allgemeine Zeitung, 4 Aug. I952, I.

74 Neumann, Medien und die Flüchtlingsfrage, 287.

75 Ibid., 273. 
had been expelled from their homes', it also asked: 'is it really so incomprehensible that in their hearts lives the desire to return home?"76 In September I949 the assistant editor-in-chief of Die Zeit, Ernst Friedlaender, branded the Oder-Neisse Line an 'injustice' (Unrecht). ${ }^{77}$ And in the same article Friedlaender defended the legitimacy of the 'right to the homeland': 'but as long as there are powers that trample the right autocratically under foot, demanding the right won't bring the old homeland back to anybody'. ${ }^{78}$ Five months later, in March I950, the Süddeutsche Zeitung attacked the Allies in an unusually bitter and sardonic tone:

So where is the root of the evil? Three men ${ }^{79}$ of world-famous humanity . . . signed that Potsdam Agreement, which made the transplantation of the population (to be conducted 'in an orderly and humane manner') into a prerequisite for the coming peace and thereby introduced a war measure out of the barbarian age into the organisation system of the modern world. ${ }^{80}$

In addition to the vivid anti-Potsdam protests, which found support among the vast majority of the West German public, ${ }^{81}$ attempts to explicitly or implicitly equate the expulsion of the Germans from the East to the Holocaust surfaced in the West German press from 1949 on. A letter to the editor of Die Zeit commented, for instance, on the 'unprecedented misery of the uprooted compatriots from the East, the expellees' and on how 'now that I am accused for allegedly having had knowledge of crimes against humanity and for having done nothing about it, I cannot get myself to expose myself for a second time to that same, and in this case justified, accusation' ${ }^{82}$ In the same newspaper, the leading journalist Marion Gräfin Dönhoff, who had fled from East Prussia before the advancing Red Army in I945, declared: 'just as Hitler's deeds welded the Jews of the whole earth into a unity again, so have the agreements of the Allies in Yalta ${ }^{83}$ and Potsdam bound together the expelled and disenfranchised East Germans into a community of fate'. ${ }^{84}$ And the Süddeutsche Zeitung reported on a representative of the conservative Bavaria Party, who in a Bundestag debate on the distribution of the refugees across West Germany, called the expulsion of the Germans from the East and the extermination of the Jewish people by the National Socialists 'the two great crimes of the last fifteen years'. ${ }^{85}$ This last example illustrates that in the first post-war decade, the West German public at large was still not, as Robert Moeller emphasised, 'ready to hear a more complex account of the National

\footnotetext{
76 Passauer Neue Presse, I3 Jan. I949, I.

77 Friedlaender, Es gibt keine Flucht.

78 Ibid.

79 The 'Big Three' signatories of the Potsdam agreement were the leader of the Soviet Union, Joseph Stalin, the prime minister of the United Kingdom, Clement Attlee, and the president of the United States, Harry S Truman.

80 'Das Streiflicht' (column), Süddeutsche Zeitung, 20 Mar. I950, I.

81 Moeller, War Stories, 35 .

82 C.W. Kühns, 'Verbrechen gegen die Menschlichkeit', Die Zeit, 8 Sept. I949, I6.

83 At the Yalta Conference of February 1945, the president of the United States, Franklin D. Roosevelt, the prime minister of the United Kingdom, Winston Churchill, and Stalin agreed that in a future peace settlement Poland would receive territories from Germany.

84 Marion Gräfin Dönhoff, 'Aufstand der Vertriebenen und Entrechteten', Die Zeit, 20 July I950, I.

85 Süddeutsche Zeitung, 24 Mar. I950, I.
} 
Socialist regime and the war'. In fact, 'in the I950s, few Germans acknowledged their responsibility for the crimes of the Third Reich or the extent of their identification with Hitler and National Socialism'. ${ }^{86}$

In order to substantiate the equation of the Holocaust and the expulsion, some press articles equalled Nazi concentration camps and prisons to Czechoslovak detention sites established for ethnic Germans designated for deportation. In an article entitled 'War Crimes', Der Spiegel highlighted, for instance, that the camp Kaunitz-College near the Moravian city Brno had served during the Nazi period as a 'German KZ' (concentration camp) ${ }^{87}$ and that 'after 1945 , the Czechs used it for the same purpose. Only the inmates changed'. ${ }^{88}$ In another article entitled 'Vertriebene. So That They Can Cry', the magazine spoke of 'the Czech KZ Neu-Rohlau near Karlsbad' (Karlovy Vary). ${ }^{89}$ Moeller's observation that, in their post-war testimonies, expellees often compared their suffering to the suffering of Jews persecuted by National Socialists and thereby 'acknowledged - directly or indirectly - the crimes committed by Nazis, yet they did so by describing their own collective suffering, not their collective accountability [for the Nazi crimes] ${ }^{90}$ is thus also valid for our analysis. Our examples also show that the more the West German public discourse put the expulsion of the German minorities from the East on an equal footing with the Holocaust, and the more these two events were subsumed under the catchphrase 'crimes against humanity', the more the term expellees was loaded with both a revisionist meaning and a moralising overtone.

Beginning in I949, then, the West German press dared to address controversial topics that could be associated with the Germans from the East, such as their return to areas they had been forced to leave, a supposed German right to territories in Central and Eastern Europe, Allied crimes against German civilians and the juxtaposition of the expulsion and the Holocaust. ${ }^{91}$ A closer look at West German newspapers reveals that, as a rule, articles that dealt with these sensitive issues either invoked expellee publications or cited people who self-identified as expellees. This shows that in practice newspaper editors could only express such controversial claims, which were dear to many Germans, through the mouths of Germans from the East. Being able to portray a large population of Germans as victims of crimes against humanity, backed by chilling first-hand accounts of violence and persecution, was an asset for West Germans faced with allegations of (at the very least) complicity in the Holocaust and in other crimes committed by the National Socialists. In this way, their self-perception as people who had suffered from the war no less than others could be supported and their quest to redeem their public image could be bolstered.

\footnotetext{
86 Moeller, War Stories, I74.

87 Between 4 January I940 and April I945, the former student residence building served as a Gestapo prison. See www.bundesarchiv.de/zwangsarbeit/haftstaetten/index.php?action=2.2\&id=23I9 (last visited 23 Aug. 20I6).

88 Der Spiegel, II Apr. I95I, 7.

89 'Vertriebene. Damit sie weinen können', Der Spiegel, I9 Jan. I950, 9.

90 Moeller, War Stories, 78.

91 For references on the German victim discourse, see the literature listed in note 9.
} 


\section{Conclusion}

This article has offered a new explanation for the growing popularity of the term Vertriebene in post-war Western Germany. By acknowledging the well-researched semantic influences of both the US military government and the expellee leadership on the Western German public discourse and its terminology regarding the Germans from the East, and by following Robert Moeller's line of reasoning, we argued that the high acclaim of the term expellees was also due to the strong symbolic political benefit it offered West Germans. Initially, the Western German public had not accepted the newcomers as 'real Germans'. Yet, over the span of a few years it discovered how society as a whole could gain from appreciating their experience and suffering during the expulsion. Calling the ethnic Germans 'expellees' (and endorsing 'expellees from the homeland' as well), integrating them into society and making their fate a central element of post-war German identity enabled the West Germans to construct and strengthen their self-image as victims. Subsequently, this allowed them to conjure a collective identification in which victimhood balanced out guilt for the Nazi crimes, at least to a degree. This was no small feat in the early postwar years and it was especially instrumental in West Germany's efforts to reintegrate in 'the community of nations'. As a result, the initial rejection of the Germans from the East as foreigners and merely 'refugees' turned into acceptance of their preferred terminology, alongside an endorsement, by and large, of their political demands. In I952 the Sonntagsblatt of Hamburg summed up this process rather optimistically: 'the rift between locals and expellees, between haves and have-nots, has run through our people [unser Volk] for seven years. . . . Where the integration succeeded, the rift is not as strongly felt anymore. ${ }^{92}$ This does not mean that the sense of foreignness felt in direct encounters between the locals and the newcomers disappeared in the coming years. Yet, on a national level, the identification of the latter as Vertriebene and as equal members of the German Volk became an asset for West Germany. At least in public discussion, as reflected in the press, they had become full-fledged, equal partners and an important element of West German society.

92 Sonntagsblatt, 2I Sept. I952. Quote from Jung, Nieh and Böke, Ausländer und Migranten im Spiegel der Presse, 77. 